\title{
ISH03
}

\section{Benissa, Alicante. España}

\author{
ISH03 \\ Benissa, Alicante. Spain
}

nomarq | estudi d'arquitectura

estudi@nomarq.com

https://doi.org/10.4995/CIAB8.2018.7401
Resumen: Un remanso desde el que contemplar la naturaleza en un paisaje que tiene como telón de fondo al Mar Mediterráneo... se concibe la totalidad del territorio como materia de proyecto. Respetar al máximo el lugar, la naturaleza y potenciar al máximo la contemplación y disfrute de este entorno natural son los factores que determinan los puntos de partida en el diseño de esta vivienda.

La idea de este proyecto nace de la propia morfología del lugar, proyectando desde y para el entorno. Bajo esta premisa se lleva a cabo la construcción de este edificio, supeditando el uso y la ubicación de la vivienda a la geometría de la parcela y adaptándose tanto a la orientación como a las vistas del solar.

Proponemos una arquitectura de territorio, que la presencia de nuestra construcción impulse a imaginarse el lugar donde se erige. Un edificio que parezca estar fuertemente enraizado en el suelo, que de la impresión de ser una parte natural de su entorno. Como dice Peter Zumthor en su libro Pensar la Arquitectura: "Despierta toda mi pasión poder proyectar edificios que, con el correr del tiempo, queden soldados de esta manera natural con la forma y la historia del lugar donde se ubican."

Palabras clave: Hormigón; Piedra; Arquitectura; Mediterráneo; Emocionalismo.
Abstract: A haven in which one can contemplate nature in a landscape with the Mediterranean Sea as backdrop... the entire territory is conceived as an additional material in the project. The respect to the settings and the surrounding nature, as well as maximizing both contemplation and enjoyment of this natural environment, are the key factors that determine the starting points in the design of this dwelling.

The idea of this project arises from the own morphology of the site, designing from and for its setting. Under this premise, the construction of a detached house is carried out, subjecting the use and location of the house to the plot's geometry and adapting it both to the site's orientation and the views.

We propose architecture of territory, that the presence of our construction impels us to imagine the place where it is erected. A building that seems to be strongly rooted in the ground, that give us the impression of being a natural part of its environment. As Peter Zumthor says in his book Thinking Architecture: "It awakens all my passion to project buildings that, with the passage of time, remain anchored in this natural way with the form and history of the place where they are located."

Key words: Concrete; Stone; Architecture; Mediterranean; Emotionalism. 


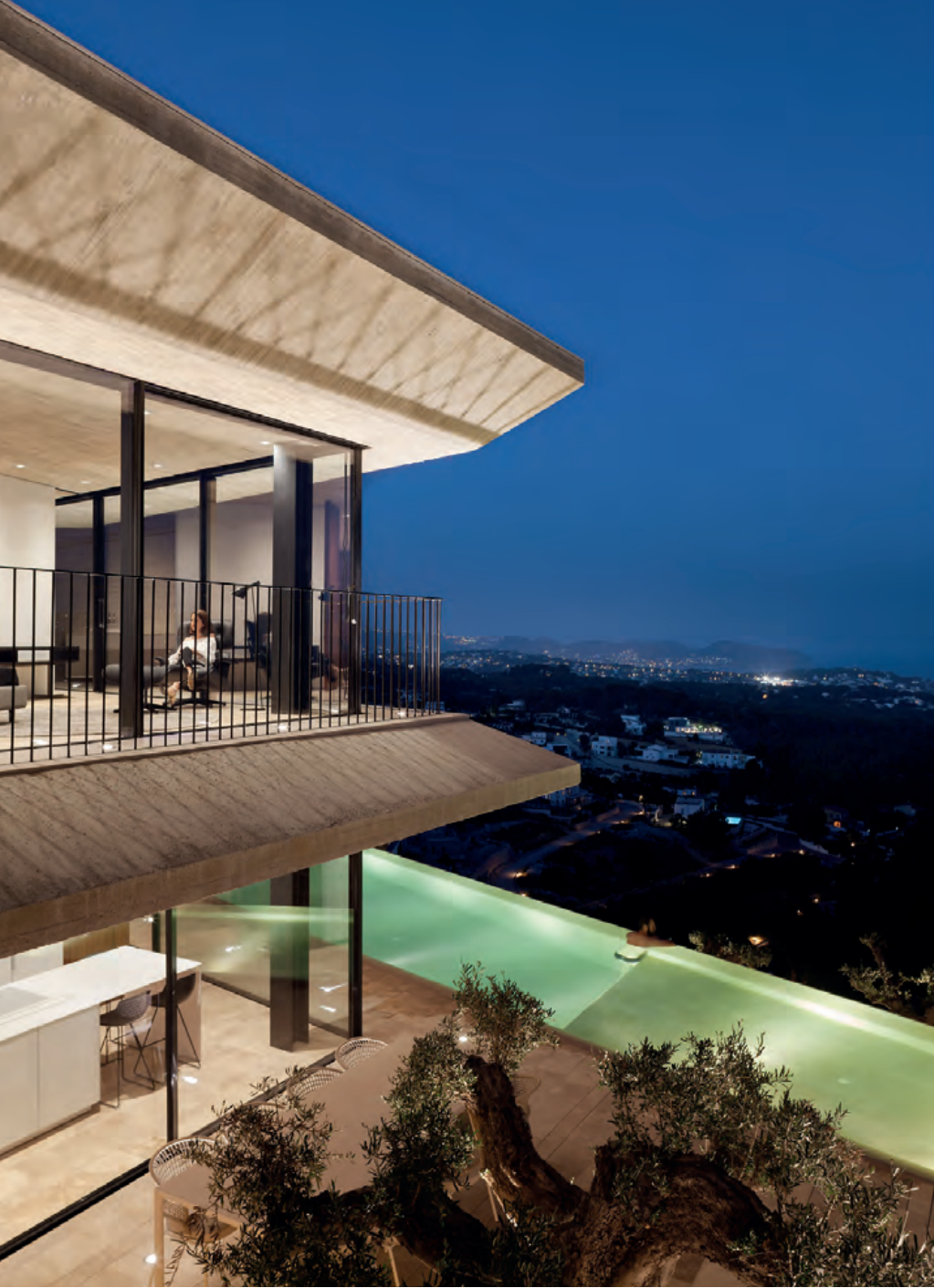

Figura 2. Jardín ish03. OMilena Villalba (2017) / Figure 2. Garden ish03. (OMilena Villalba (2017)

Vemos en la arquitectura mediterránea una tradición constructiva que ha sabido hallar soluciones apropiadas a cada uno de los problemas que las necesidades reales del hombre que debía vivir en aquel clima, en aquel lugar; soluciones tan logradas que no requerían ni proceso de renovación, ni puesta al día, arquitectura atemporal.

Josep Lluís Sert pronunció en una conferencia de 1934 para la Asociación de Alumnos de la Escuela Superior de Arquitectura de Barcelona: "Debemos defender una arquitectura de clima, una arquitectura mediterránea hecha para un sol intenso, una atmósfera diáfana y un paisaje amable. Arquitectónicamente no podemos respetar otras fronteras que las naturales, geográficas, eternas... El camino en el momento actual no ha de ser ni copiar la arquitectura de otras épocas, ni los estilos históricos, ni la decoración de barcos, ni funcionalismos mal entendidos. Sino que ha de ser una arquitectura de hoy, viva, palpitante y joven, creación constante. $Y$ en cada caso, clara solución a un programa, a un problema planteado"2

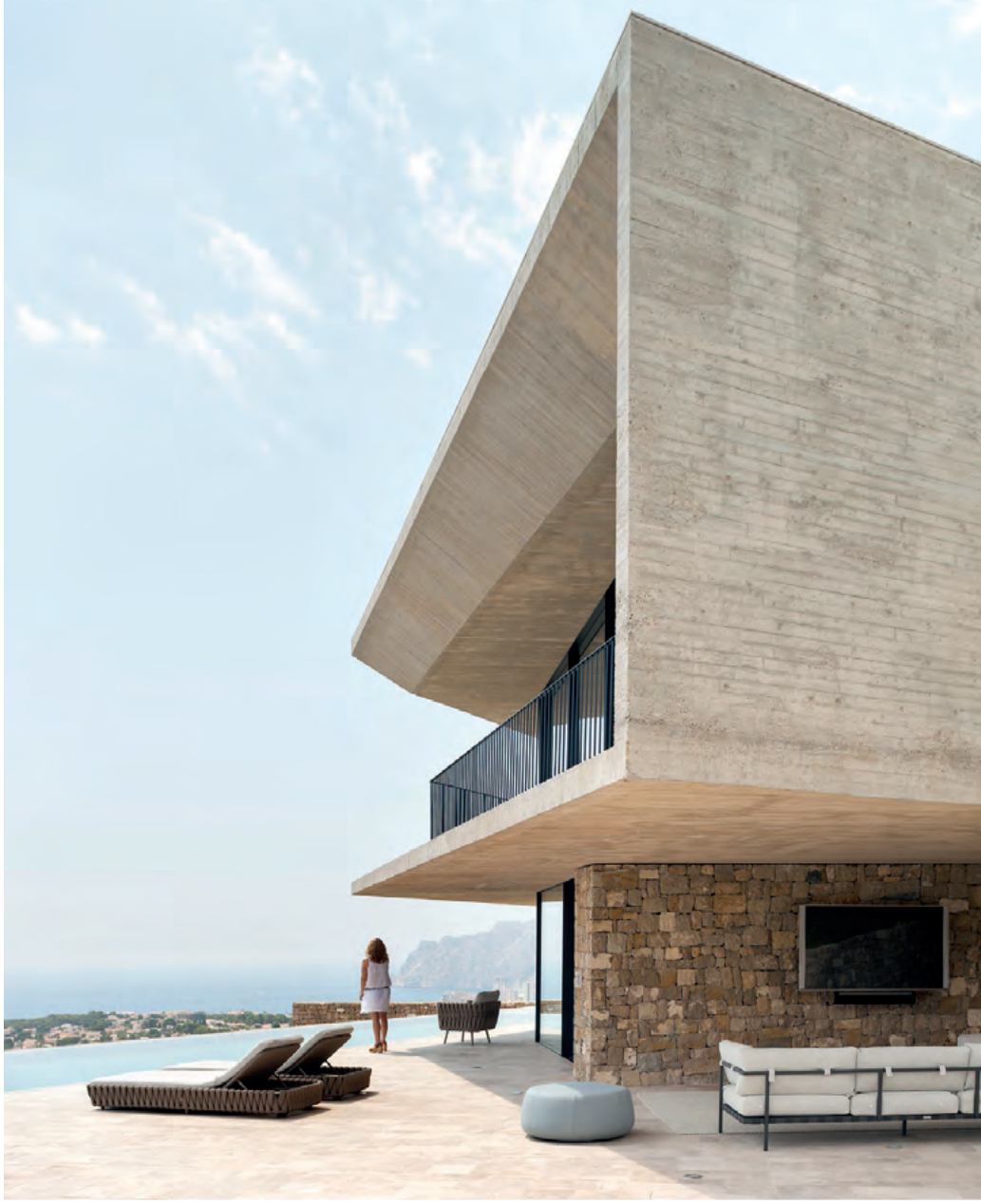

Figura 3. Piscina ish03. CMilena Villalba (2017) / Figure 3. Swimming pool ish03. CMilena Villalba (2017)

We see in the Mediterranean architecture a constructive tradition that has been able to find appropriate solutions to each one of the problems that the real needs of the man who had to live in that climate, in that place; solutions that were so successful that they did not require a renovation process or updating, timeless architecture.

Josep Lluís Sert said at a conference in 1934 for the Alumni Association of the Barcelona School of Architecture: "We must defend a climate architecture, a Mediterranean architecture made for an intense sun, a clear atmosphere and a friendly landscape. In the architectural sense we cannot respect other borders than natural, geographical, eternal ... The way at the present time should not be to copy the architecture of other eras, or historical styles, or the decoration of ships, or misunderstood functionalisms. But it has to be architecture of today, alive, pulsating and young, constant creation. And in each case, clear solution to a program, to a problem raised" 2 

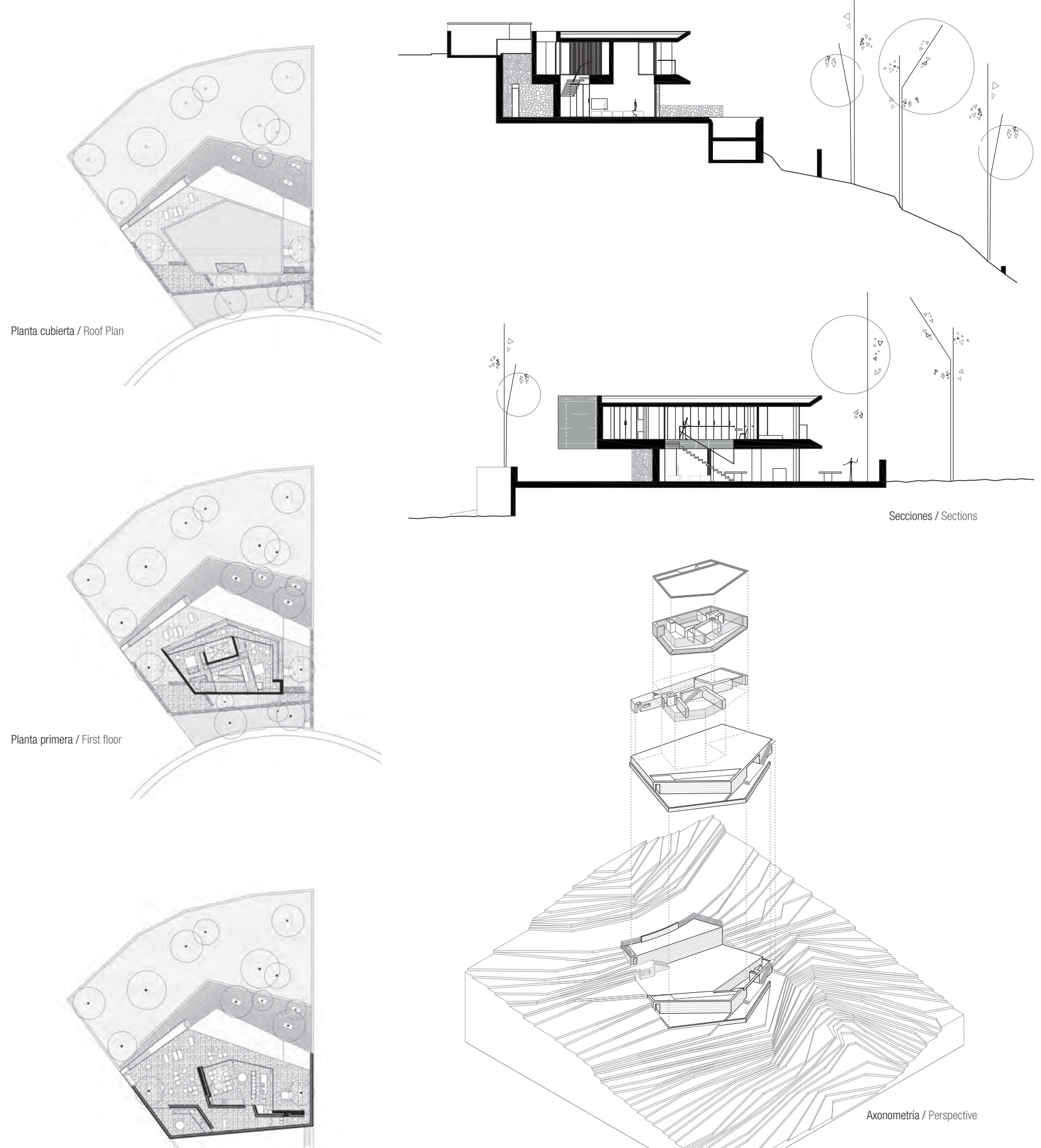

Planta baja / Ground floor

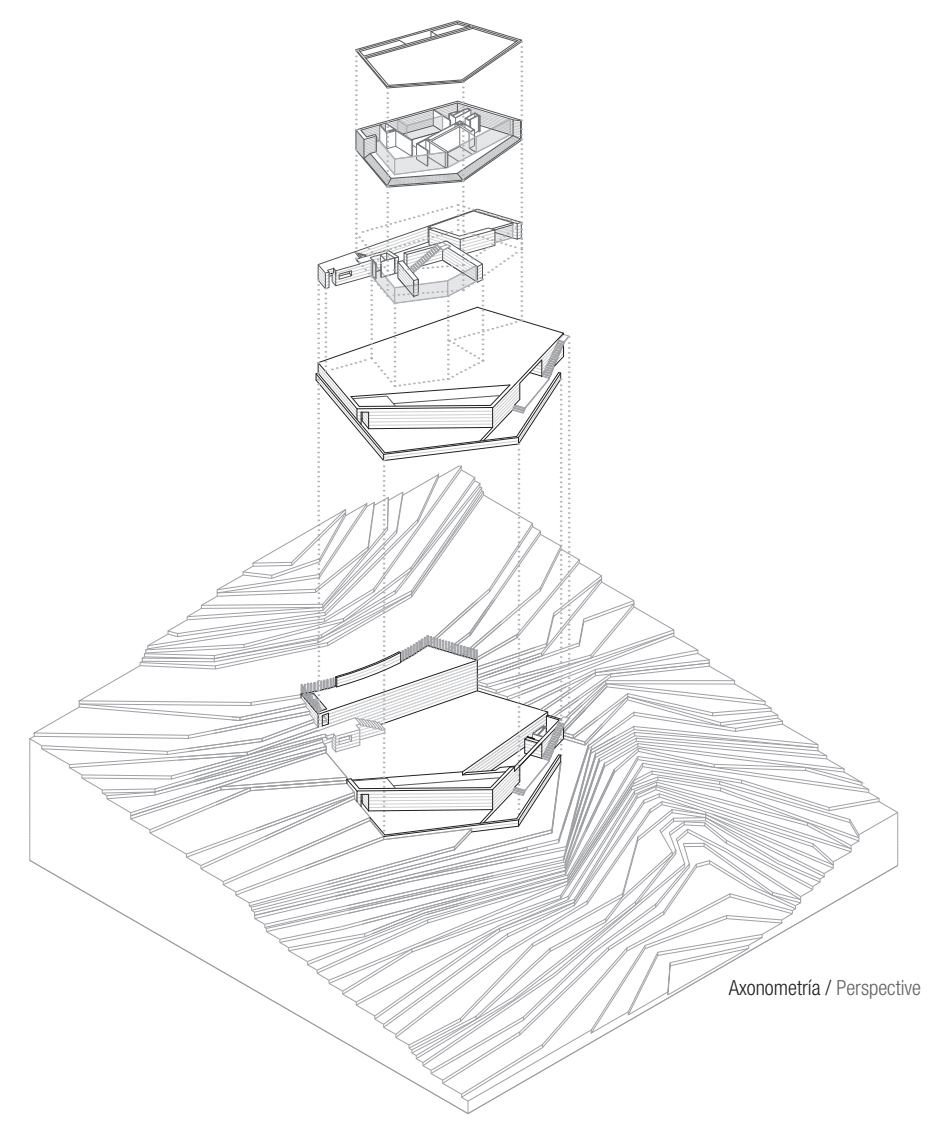



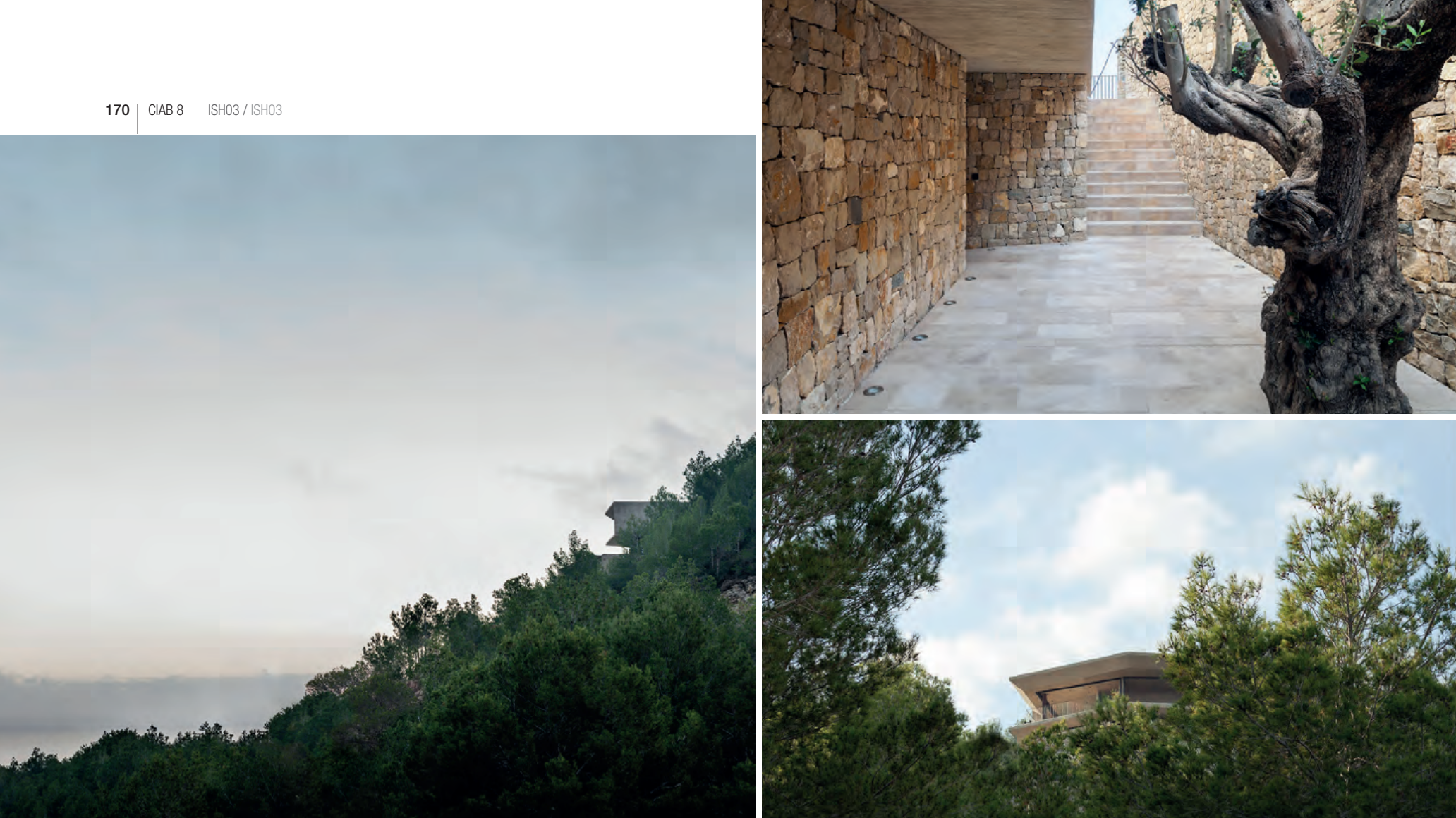

Figura 4. Entorno ish03. @Milena Villalba (2017) / Figure 4. Surroundings ish03. @Milena Villalba (2017)

Figura 5. Patio acceso ish03. OMilena Villalba (2017) / Figure 5. Patio ish03. CMilena Villalba (2017).

Figura 6. Entorno ish03. @Milena Villalba (2017) / Figure 6. Surroundings ish03. @Milena Villalba (2017).

Como resultado del estudio del programa, el lugar y su contexto, se plantea una construcción de un volumen de hormigón apoyado sobre muros de piedra del lugar, distribuyéndose el programa de noche en el volumen de hormigón, y el programa de día en planta baja abierta, la cual está directamente relacionada con los diferentes espacios exteriores. Situada en una zona privilegiada con vistas al Mar Mediterráneo, la vivienda contrasta respetuosamente con el protagonismo de su entorno y es un muro de piedra tradicional el que interactúa con la topografía del lugar para salvar el desnivel y generar el recorrido de acceso a la vivienda.

El volumen, situado estratégicamente sobre la planta libre inferior y con un tratamiento estratégico de cada fachada, se abre y se cierra al paisaje en función de su orientación creando un diálogo permanente con el entorno, captando las vistas preferentes y generando zonas en sombra en la planta inferior. En la planta inferior el vuelo del volumen se convierte en un elemento clave que protege de la radiación directa del sol generando zonas de sombra que prolongan el espacio interior hacia las terrazas que rodean la vivienda.

La vivienda se organiza para disfrutar de la orientación más conveniente para cada planta y consigue prolongar las vistas de cada estancia hacia la terraza, la lámina de agua de la piscina y el horizonte.
As a result of the study of the program, the place and its context, a construction of a volume of concrete supported on stone walls of the place is proposed, distributing the night program in the volume of concrete, and the day program in open ground floor, which is directly related to the different outdoor spaces. Located in a privileged area overlooking the Mediterranean Sea, the house contrasts respectfully with the prominence of its environment and it is a traditional stonewall that interacts with the topography of the place to join the different levels and generate access to the home.

The volume strategically located on the lower free floor and with a strategic treatment of each façade, opens and closes to the landscape according to its orientation creating a permanent dialogue with the environment, capturing the preferred views and generating shadow areas in the lower floor. On the lower floor the flight of the volume becomes a key element that protects from the direct radiation of the sun generating shadow areas that extend the interior space to the terraces that surround the house.

The house is organized to enjoy the most convenient orientation for each floor and manages to extend the views of each room towards the terrace, the pool and the horizon. The materiality of the house seeks elegance and simplicity with a spatial structure of reinforced seen concrete. 


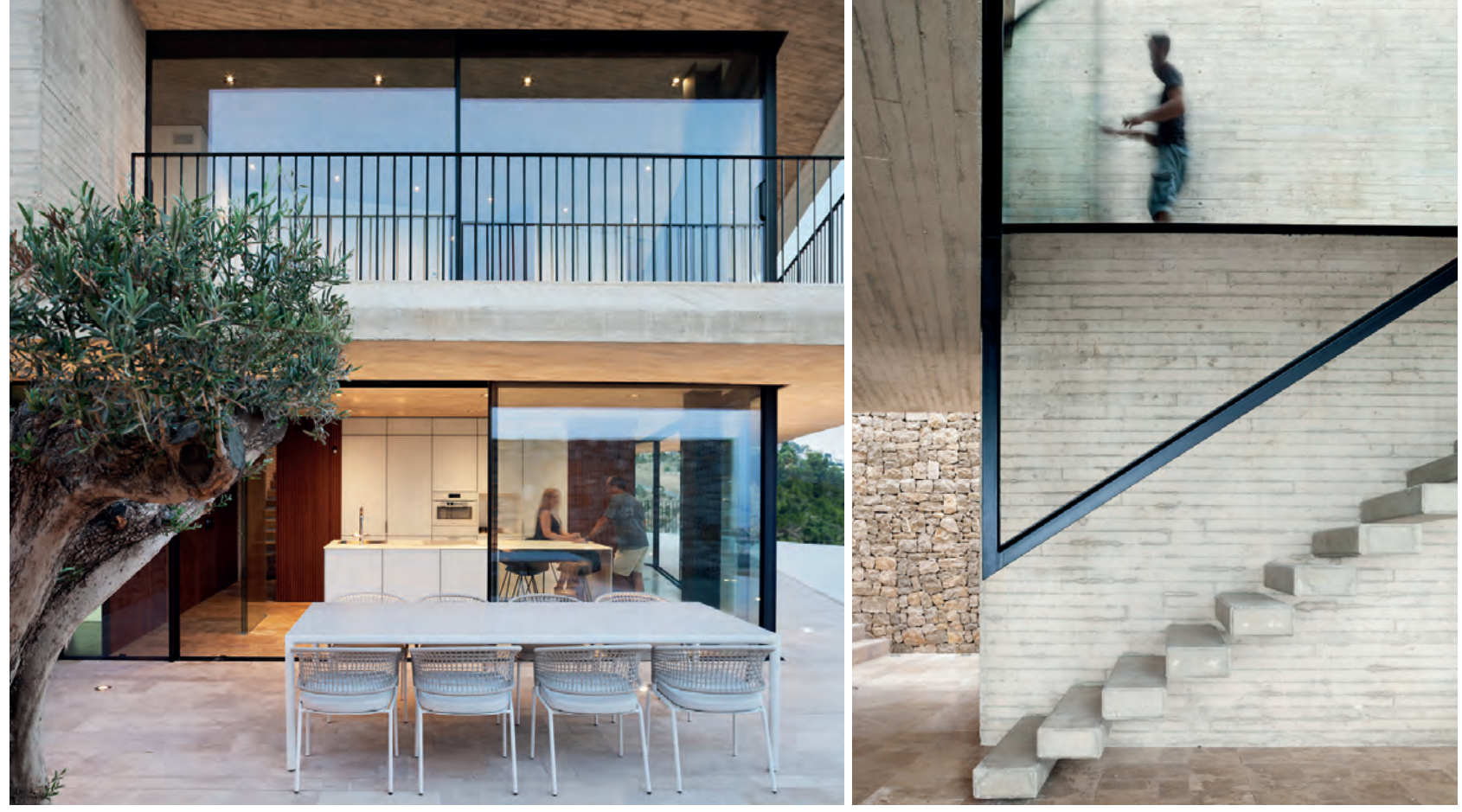

Figura 9. Cocina ish03. CMilena Villalba (2017) / Figure 9. Kitchen ish03. CMilena Villalba (2017).

Figura 10. Escalera hormigón ish03. CMilena Villalba (2017) / Figure 10. Concrete staircase ish03. CMilena Villalba (2017).

\section{Materialidad. Nobleza, sobriedad y elegancia}

La materialidad de la vivienda busca nobleza, sobriedad y elegancia. Los materiales predominantes son el hormigón visto y la piedra del lugar, de gran calidez por su tonos dorados y su textura, generando espacios agradables en el interior y unos volúmenes rotundos y contundentes al exterior.

La idea de arquitectura expresada en este proyecto, no sólo se aparta de las edificaciones de su entorno en lo relativo a su solución constructiva, sino que necesariamente el lenguaje arquitectónico empleado está tremendamente alejado del que en general se utiliza en toda la urbanización. Se trata de un proyecto moderno que remite en programa, forma, estructura y construcción a la identificación de los requerimientos exigidos de manera unitaria y con un enfoque atemporal.

\section{Descripción del proyecto. Programa de necesidades}

Potenciar los diferentes recorridos a través de la compresión y la descompresión, las relaciones visuales entre los diferentes espacios, la prolongación del programa de día hacia el exterior y las visuales... a través de esta intensa relación con el lugar entendemos que nuestra obra debe transmitir emoción, como contenido esencial e inmaterial de la arquitectura.

El programa de necesidades se distribuye en zona de día en planta inferior y zona de noche en planta superior. Unos espacios continuos y fluidos que se abren a la naturaleza proporcionando relaciones visuales interior-exterior y con la atención puesta en los detalles convierten a cada espacio de la vivienda en una estancia singular y exclusiva.
Materiality. Nobility, sobriety and elegance

The materiality of the house seeks nobility, sobriety and elegance. The predominant materials are the exposed concrete and the stone of the place, of great warmth for its golden tones and its texture, generating pleasant spaces in the interior and strong and resounding volumes to the exterior.

The idea of architecture expressed in this project, not only departs from the buildings of its environment in relation to its constructive solution, but necessarily the architectural language used is tremendously removed from the one that is generally used throughout the development. It is a modern project that refers in program, form, structure and construction to the identification of the requirements demanded in a unitary way and with a timeless approach.

\section{Project description. Needs of program}

Enhance the different routes through compression and decompression, the visual relationships between the different spaces, the extension of the day program to the outside and the visuals... through this intense relationship with the place we understand that our work must convey emotion, as essential and immaterial content of architecture.

The needs program is distributed in the day area on the lower floor and the night area on the upper floor. A continuous and fluid space that opens to nature providing indoor-outdoor visual relationships and attention to details make each space of the home a unique and exclusive stay. 
